\title{
PENGARUH BEBAN KERJA DAN STRESS KERJA MELALUI KELELAHAN KERJA TERHADAP KINERJA PERAWAT DI RUANG RAWAT INAP RUMAH SAKIT ISLAM FAISAL MAKASSAR
}

\author{
Ratna Malawat' ${ }^{1}$ asyidin Abdullah² Andi Nurlinda ${ }^{3}$
}

\author{
${ }^{1}$ Universitas Muslim Indonesia \\ ${ }^{2}$ Universitas Muslim Indonesia \\ ${ }^{3}$ Universitas Muslim Indonesia
}

Alamat korespondensi: (ratnamalawatrm@yahoo.com/085299920262)

\begin{abstract}
ABSTRAK
Masalah beban kerja, stress kerja dan kelelahan kerja yang tinggi sangat berhubungan dengan kesehatan kerja dan produktivitas kerja pada perawat. Pembenahan rasio perawat dan pengkajian ulang masalah beban kerja perawat merupakan suatu strategi bagi Rumah Sakit sebagai organisasi kesehatan untuk mengatur tentang tugas pokok utama perawat secara jelas agar mengurangi beban kerja yang tinggi dan efek kelelahan pada perawat serta meningkatkan keselamatan pasien dan perawat, dikarenakan kinerja perawat berhubungan dengan mutu pelayanan keperawatan yang berpengaruh terhadap kepuasan pasien. Penelitian ini bertujuan untuk mengetahui pengaruh beban kerja dan stress kerja melalui kelelahan kerja terhadap kinerja perawat di Ruang Rawat Inap Rumah Sakit Islam Faisal Makassar. Jenis penelitian ini adalah penelitian kuantitatif dengan menggunakan metode analisis jalur (path analysis). Sampelnya adalah 76 responden responden. Pengumpulan data dilakukan dengan wawancara melalui kuesioner. Hasil penelitian menyimpulkan ada pengaruh yang signifikan antara beban kerja terhadap kelelahan kerja dengan nilai $p=0,019<0,05$, stress kerja terhadap kelelahan kerja dengan nilai $p=0,000<0,05$, kelelahan kerja terhadap kinerja dengan nilai $p=0,000<0,05$, beban kerja terhadap kinerja perawat dengan nilai $p=0,001<0,05$, ada pengaruh yang signifikan antara beban kerja terhadap kinerja perawat melalui kelelahan kerja dengan nilai signifikansi beban kerja sebesar $p=0,001$ dan tidak ada pengaruh yang signifikan antara stress kerja terhadap kinerja dengan nilai $p=0,185>0,0$. Pihak manajemen Rumah Sakit Islam Faisal perlu memperhatikan dan mengatur kembali faktor - faktor seperti beban kerja, stress kerja dan kelelahan kerja dengan baik serta faktor lingkungan dan sarana prasarana Rumah Sakit yang membuat para perawat merasa nyaman saat bekerja.
\end{abstract}

Kata Kunci : Beban Kerja, Kelelahan Kerja, Kinerja Perawat, Stress Kerja

\section{PENDAHULUAN}

Karena sifat alamiah dari pekerjaannya, perawat adalah kelompok tenaga kesehatan yang beresiko tinggi mengalami kelelahan kerja dibanding tenaga kesehatan lainnya (Lorenz et al, 2010). Kelelahan kerja secara fisik, mental dan emosional disebut juga dengan burnout, sindrom ini akibat dari stress kerja yang berkepanjangan karena stress yang dialami terjadi pada jangka waktu yang cukup lama. Kelelahan kerja berhubungan dengan stress pekerjaan yang berpotensi negatif terhadap kesehatan fisik dan psikologis individu serta berdampak pada efektifitas suatu organisasi (Huber, 2006).

Banyaknya tugas perawat dalam memberikan pelayanan baik pelayanan keperawatan dan non keperawatan menyebabkan terabaikannya tugas utama perawat yang berorientasi pada pasien dalam melakukan asuhan keperawatan (Mellawani, 2017). Hal tersebut sangat penting karena berkaitan dengan dampak yang ditimbulkan akibat meningkatnya beban kerja perawat yang berhubungan dengan keselamatan pasien, kepuasan pelanggan dan kinerja perawat. Banyak faktor yang mempengaruhi belum optimalnya kinerja perawat, salah satunya adalah tingginya beban kerja perawat. Beban kerja yang tinggi akan menimbulkan terjadinya kelelahan kerja, yang mana memberi kontribusi sebesar $50 \%$ terhadap kejadian kecelakaan kerja.

Sebanyak 50,9\% perawat Indonesia sendiri mengalami stress kerja, kurang istirahat akibat dari beban kerja yang terlalu tinggi (PPNI, 2006). Dampak dari stress kerja, kelelahan kerja, beban kerja yang tinggi bagi perawat dapat menurunkan kinerja keperawatan seperti pengambilan keputusan yang buruk, kurang konsentrasi, apatis, kelelahan fisik, dan kecelakaan kerja sehingga pemberian asuhan keperawatan tidak maksimal. Masalah beban kerja yang tinggi pada perawat di Indonesia 
sendiri belum sejalan dengan Keputusan Menteri Kesehatan RI No. 33 tahun 2015 mengenai perencanaan sumber daya kesehatan (beban kerja dan standar ketenagaan minimal dan analisa kerja) yang belum optimal, dimana masih banyak organisasi RS belum memperhatikan hal tersebut.

\section{BAHAN DAN METODE}

Lokasi, Populasi, dan Sampel

Jenis penelitian ini adalah penelitian kuantitatif dengan menggunakan metode analisis jalur (path analysis). Analisis ini digunakan untuk menganalisis hubungan sebab akibat yang inheren antar variabel yang disusun menggunakan koefisien jalur sebagai besaran nilai dalam menentukan besarnya pengaruh variabel eksogen (independen) terhadap variabel endogen (dependen). Populasi dari penelitian ini adalah keseluruhan perawat yang bertugas di ruang rawat inap Rumah Sakit Islam Faisal Makassar yang berjumlah 120 responden. Teknik sampling pada penelitian ini adalah menggunakan probability sampling dengan jumlah sampel dalam penelitian ini adalah 76 responden responden.

\section{Pengumpulan data dan pengolahan data Data primer}

Data primer adalah Pengumpulan data pada penelitian ini menggunakan kuesioner dan pengukuran langsung pada sampel penelitian. di ruang rawat inap Rumah Sakit Islam Faisal Makassar yang memberikan jawaban di dalam kuesioner.

Data sekunder adalah data yang diperoleh dari rekamedik dari Rumah Sakit Islam Faisal Makassar.

\section{Analisis Data}

1. Analisis Univariat

Dilakukan untuk satu variabel atau per variabel. Setelah dilakukan tabulasi data, kemudian data diolah dengan menggunakan metode uji statistik yaitu analisis univariat dilakukan untuk variabel tunggal yang dianggap terkait dengan penelitian

2. Analisa Bivariabel

Analisis jalur bertujuan untuk mengetahui pengaruh langsung maupun tidak langsung variabel eksogen (bebas) terhadap variabel endogen(terikat) dengan signifikansi ( sigma F) $\rho=\leq 0,05$ dan signifikansi (sigma T) $\rho=\leq 0,05$.

\section{HASILPENELITIAN}

\section{Analisis Univariat}

Tabel 1 Distribusi responden berdasarkan umur, pendidikan, dan pekerjaan di wilayah Puskesmas Cina Kabupaten Bone tahun $2014(\mathrm{n}=38)$

\begin{tabular}{|c|c|c|}
\hline karakteristik & $\mathrm{n}$ & $\%$ \\
\hline $21-30$ & 67 & 88,2 \\
$31-40$ & 6 & 7,9 \\
$41-50$ & 1 & 1,3 \\
$>50$ & 2 & 2,6 \\
\hline $\begin{array}{c}\text { Pendidikan } \\
\text { SPK }\end{array}$ & 1 & 1,3 \\
D3 & 37 & 48,7 \\
S1 & 38 & 50,0 \\
\hline Jenis & & \\
kelamin & 26 & 34,2 \\
Laki & & 65,8 \\
Perempuan & 50 & \\
\hline Masa & & \\
Pekerjaan & 67 & 88,2 \\
$<10$ tahun & 9 & 11,8 \\
$=>10$ tahun & & \\
\hline
\end{tabular}

Berdasarkan tabel 1 dapat diketahui umur responden dalam penelitian ini bervariasi, dimana responden kelompok usia 21-30 tahun berjumlah 67 responden $(88,2 \%)$, kelompok usia $31-40$ tahun berjumlah 6 responden 6 responden $(7,9 \%)$, kelompok usia 41-50 tahun berjumlah 1 responden $(1,3 \%)$, dan kelompok usia $>50$ tahun berjumlah 2 responden $(2,6 \%)$. Hal ini berarti sebagian besar responden berusia antara 21-30 tahun. Menurut jenis kelamin perempuan, yaitu sebanyak 50 responden $(65, \%)$ dan laki-laki sebanyak 26 responden (34,2\%). sebagian besar berpendidikan S1 Keperawatan sebanyak 38 responden $(50,0 \%)$, D3 Keperawatan sebanyak 38 responden $(48,7 \%)$ dan SPK hanya 1 responden $(1,3 \%)$. Hal ini berarti sebagian besar responden adalah lulusan S1. masa kerja responden yang paling banyak <10 tahun sebanyak 67 responden $(88,2 \%)$ dan $>10$ tahun sebanyak 9 responden $(11,8 \%)$. Hal ini berarti sebagian besar responden memiliki masa kerja $<10$ tahun

Tabel 2 Deskripsi frekuensi pengaruh beban kerja di Ruang Rawat Inap Rumah Sakit Islam Faisal Makassar.

\begin{tabular}{|c|c|c|}
\hline Beban Kerja & $\mathrm{n}$ & $\%$ \\
\hline Rendah & 24 & 31,6 \\
Tinggi & 52 & 68,4 \\
\hline Total & 76 & 100 \\
\hline
\end{tabular}


Berdasarkan tabel 2 bahwa dari 76 responden yang menunjukkan beban kerja rendah berjumlah 24 responden $(31,6 \%)$ dan 52 responden $(68,4 \%)$ yang menunjukkan beban kerja tinggi. Hal ini sesuai dengan pernyataan responden bahwa jumlah perawat diruangan belum sesuai dengan jumlah pasien serta kepala ruangan kurang memperhatikan kenyamanan kerja bawahan sehingga membuat beban pekerjaan perawat semakin bertambah tinggi. Selain itu faktor beban pekerjaan yang terkadang tidak sesuai dengan kemampuan dan tidak semestinya dilakukan oleh perawat seperti masih ada beberapa perawat yang membersihkan dan mengepel ruangan serta membuang sampah medisyang semestinya dilakukan oleh petugas kebersihan, sehingga membuat beban pekerjaan yang dirasakan perawat semakin bertambah tinggi.

Tabel 3. Deskripsi frekuensi pengaruh stress di Ruang Rawat Inap Rumah Sakit Islam Faisal Makassar.

\begin{tabular}{|c|c|c|}
\hline Stress & $\mathrm{n}$ & $\%$ \\
\hline Tidak Stress & 30 & 39,5 \\
Stress & 46 & 60,5 \\
\hline Total & 76 & 100 \\
\hline
\end{tabular}

Berdasarkan tabel 3 . bahwa 76 responden yang tidak stress berjumlah 30 responden $(39,5 \%)$ dan 46 responden $(60,5 \%)$ yang menunjukkan stress. Hal ini disebabkan karena tuntutan pekerjaan yang tinggi sehingga perawat merasa kurang fokus terhadap pekerjaan, sehingga membuat perawat sering absen atau tidak masuk kerja. Selain itu ada beberapa perawat yang mengatakan bahwa pembagian tugas masing-masing yang dirasa kurang puas seperti terkadang masih saja ada tugas dan jadwal pemeriksaan fisik atau penggantian infus yang seharusnya dilakukan oleh perawat lain, tetapi didelegasikan kepada perawat lainnya yang membuat perawat semakin stress ditempat kerja sehingga faktor stress yang tinggi tersebut semakin meningkatkan jumlah absensi atau ketidakhadiran perawat di tempat kerja.

Tabel 4. Deskripsi frekuensi pengaruh kelelahan kerja di Ruang Rawat Inap Rumah Sakit Islam Faisal Makassar.

\begin{tabular}{|c|c|c|}
\hline $\begin{array}{c}\text { Kelelahan } \\
\text { Kerja }\end{array}$ & $\mathrm{n}$ & $\%$ \\
\hline TidakLelah & 29 & 38,2 \\
Lelah & 47 & 61,8 \\
\hline Total & 76 & 100 \\
\hline
\end{tabular}

Berdasarkan tabel 4. menunjukkan bahwa dari 76 responden yang tidak mengalami kelelahan kerja yaitu 29 responden $(38,2 \%)$ dan 47 responden $(61,8 \%)$ yang mengalami kelelahan kerja.Hal ini sesuai dengan pernyataan responden yang mengatakan bahwa faktor beban kerja dan stress kerja yang tinggi menjadi penyebab terjadinya kelelahan di tempat kerja, sehingga membuat perawat tidak dapat berkonsentrasi terhadap pekerjaan. Selain itu masih ada beberapa perawat baru yang merasakompetensinya masih kurang dalam memberikan pelayanan keperawatan sehingga berpengaruh terhadap kinerjanya sebagai seresponden pemberi asuhan keperawatan.

Tabel 5 Deskripsi frekuensi pengaruh kinerjadi Ruang Rawat Inap Rumah Sakit Islam Faisal Makassar

\begin{tabular}{|c|c|c|}
\hline Kinerja & $\mathrm{n}$ & $\%$ \\
\hline Buruk & 31 & 40,8 \\
Baik & 45 & 59,2 \\
\hline Total & 76 & 100 \\
\hline
\end{tabular}

Berdasarkan tabel 5. menunjukkan bahwa dari 76 responden yang menunjukkan kinerja buruk berjumlah 31 responden $(40,8 \%)$ dan 45 responden $(72,4 \%)$ yang menunjukkan kinerja baik. $\mathrm{Hal}$ ini sudah sesuai dengan pernyataan responden bahwa penerapan asuhan keperawatan di rumah sakit sudah sesuai dengan alurnya yang dimulai dari pengkajian, diagnosa, rencana keperawatan sampai implementasi keperawatan.

2. Analisis Jalur (path analysis) Model 1 \& 2 Tabel 6. Uji Hipotesis Pengaruh Langsung (Direct Effect)

\begin{tabular}{|l|l|l|l|l|l|}
\hline Variabel & $\begin{array}{l}\text { Varia } \\
\text { bel } \\
\text { Endo } \\
\text { gen }\end{array}$ & $\begin{array}{l}\text { Dirrec } \\
\boldsymbol{t} \\
\text { Effect }\end{array}$ & $\begin{array}{l}\text { T } \\
\text { Hitun } \\
\mathbf{g}\end{array}$ & Sig. & $\begin{array}{l}\text { Keteranga } \\
\mathbf{n}\end{array}$ \\
\hline Model 1 & Y1 & 0,408 & 2,395 & 0,019 & $\begin{array}{l}\text { Signifikan } \\
\text { X1 }\end{array}$ \\
Y1 & 0,770 & 5,020 & 0,000 & Signifikan \\
X2 & & & & & \\
Model 2 & Y2 & 0,697 & 3,329 & 0,001 & Signifikan \\
X1 & Y2 & 0,282 & 1,339 & 0,185 & $\begin{array}{l}\text { Tidak } \\
\text { Signifikan } \\
\text { X2 }\end{array}$ \\
Y1 & Y2 & 0,725 & 5,240 & 0,000 & \\
\hline
\end{tabular}

Pengaruh langsung beban kerja terhadap kelelahan kerja, dapat dilihat dengan nilai koefisien sebesar 0,408 dengan signifikansi 0,019 . Artinya nilai koefisien bernilai positif dan mempunyai nilai signifikansi $0,000<$ 0,05 , dengan demikian beban kerja berpengaruh positif dan signifikan terhadap kelelahan kerjasehingga hipotesis 1 terbukti. 
Pengaruh langsung stress kerja terhadapkelelahan kerja, dapat dilihat dengan nilai koefisien 0,770 dengan signifikansi 0,000 . Artinya nilai koefisien bernilai positif dan mempunyai nilai signifikansi $0,000<0,05$, dengan demikian stress kerja berpengaruh positif dan signifikan terhadap kelelahan kerja sehingga hipotesis 2 terbukti.

Pengaruh langsung beban kerja, stress kerja terhadap kinerja perawat dengan nilai koefisien beban kerja 0,408 dengan signifikansi $0,019<0,05$ dan stress kerja dengan nilai koefisien 0,282 dan signifikansi $0,185>0,05$ dimana beban kerja artinya berpengaruh positif dan signifikan, stress kerja berpengaruh positif dan tidak signifikan secara gabungan terhadap kinerja perawat sehingga hipotesis 3 terbukti.

Pengaruh langsung kelelahan kerja terhadap kinerja dengan nilai koefisien sebesar 0,725 dengan signifikansi $0,000<0,05$, dengan demikian kelelahan kerjaberpengaruh positif dan signifikan terhadap kinerja perawat sehingga hipotesis 4 terbukti.

Pengaruh langsung beban kerjaterhadap kinerja dengan nilai koefisien sebesar 0,697 dengan signifikansi $0,001<0,05$ dengan demikian beban kerja berpengaruh positif dan signifikan terhadap kinerja perawat sehingga hipotesis 5 terbukti.

Ada pengaruh langsung stress kerja terhadap kinerja perawat tetapi tidak signifikan dengan nilai koefisien sebesar 0,282 dengan signifikansi $0,185<0,05$, dengan demikian stress kerja berpengaruh negatif dan tidak signifikan terhadap kinerja perawat sehingga hipotesis 6 tidak terbukti.

Pengaruh langsung beban kerja terhadap kinerja perawat melaluikelelahan kerjadengan nilai koefisien beban kerja sebesar 0,697, dengan signifikansi sebesar 0,001 sedangkan koefisien kelelahan kerja sebesar 0,725 dan signifikansi 0,000 dengan demikian pengaruh langsung kelelahan kerja lebih besar daripada beban kerja. Hal ini menunjukkan bahwa kelelahan kerja mampu memberikan pengaruh cukup besar sebagai variabel intervening sehingga hipotesis 7 terbukti.

Pengaruh langsung beban kerja, stress kerja dan kelelahan kerja secara gabungan terhadap kinerja perawat dengan nilai koefisien sebesar 0,697, $0,282, \quad 0,725$ dengan signifikansi sebesar $0,001,0,185,0,000<0,05$ dengan demikian kelelahan kerja yang paling berpengaruh positif, kemudian beban kerja berpengaruh positif terhadap kinerja perawat sedangkan stress kerja berpengaruh negatif dan tidak signifikan terhadap kinerja perawat sehingga hipotesis 8 diterima

\section{PEMBAHASAN}

1. Pengaruh Beban Kerja Terhadap Kelelahan Kerja

Hipotesis 1 menyatakan bahwa ada pengaruh langsung antara variabel beban kerja (X1) terhadapkelelahan kerja(Y1). Hipotesis ini dapat dibuktikan dengan nilai koefisien sebesar 0,408 dengan signifikansi 0,019 . Artinya nilai koefisien bernilai positif dan mempunyai nilai signifikansi $0,000<0,05$, dengan demikian beban kerja berpengaruh positif dan signifikan terhadap kelelahan kerjase hingga dapat disimpulkan bahwa variabel beban kerja (X1) berpengaruh signifikan terhadap kelelahan kerja(Y1), yaitu ada pengaruh yang bermakna antara beban kerja terhadap kelelahan kerjadi Rumah Sakit Islam Faisal Makassar. Penelitian ini sejalan dengan penelitian yang dilakukan oleh Roro Vasthy Dwi Dwi Ardhanti dan Ahmad Dwiyanto (2017) mengenai "Hubungan Persepsi Terhadap Beban Kerja Dengan Burnout Syndrome Pada Perawat" menunjukkan bahwa ada hubungan yang positif yang signifikan antara beban kerja yang mempengaruhi sindrom kelelahan kerja dengan koefisien korelasi 0,605 dengan signifikansi $p=$ $0,000<0,05$. Hal tersebut sesuai dengan penyataan responden bahwa beban kerja yang rendah maka kelelahan kerja juga semakin rendah, sebaliknya beban kerja yang semakin tinggi akan memicu angka kejadian kelelahan kerjayang tinggi.

2. Pengaruh Stress Kerja Terhadap Kelelahan Kerja

Hipotesis 2 menyatakan bahwa terdapat pengaruh langsung stress kerja (X2) terhadapkelelahan kerja(Y1). Hipotesis ini dapat dibuktikan dengan nilai koefisien 0,770 dengan signifikansi 0,000. Artinya nilai koefisien bernilai positif dan mempunyai nilai signifikansi $0,000<0,05$, sehingga dapat disimpulkan bahwa variabel stress kerja (X2) berpengaruh positif dan signifikan terhadap kelelahan kerja (Y1), yaitu ada pengaruh yang 
bermakna antara stress kerja terhadap kelelahan kerjadi Rumah Sakit Islam Faisal Makassar tahun 2018. Penelitian ini sejalan dengan penelitian yang dilakukan oleh Prestiana dan Purbandini (2012) mengenai "Hubungan Antara Efikasi Diri (Self Efficacy) Dan Stress Kerja Dengan Kejenuhan Kerja (Burnout) Pada Perawat IGD Dan ICU RSUD Kota Bekasi" dimana terdapat korelasi yang signifikan antara stress kerja dan kelelahan kerja dengan nilai $p=0,000$ $<0,05$.

3. Pengaruh Beban Kerja, Stress Kerja Terhadap Kinerja Perawat

Hipotesis 3 menyatakan bahwa terdapat pengaruh langsung beban kerja (X1), stress kerja (X2) terhadap kinerja perawat (Y2) dengan nilai koefisien beban kerja 0,408 dengan signifikansi 0,019 dan stress kerja dengan nilai koefisien 0,770 dimana keduanya mempunyai signifikansi $0,000<0,05$ dengan demikian variabel beban kerja (X1) dan stress kerja (X2) berpengaruh positif dan signifikan secara gabungan terhadap kinerja perawat (Y2), sehingga hipotesis 3 terbukti, yaitu ada pengaruh yang bermakna antara beban kerja, stress kerja terhadap kinerja perawat di Rumah Sakit Islam Faisal Makassar. Penelitian ini sejalan dengan penelitian yang dilakukan oleh Friska Aprilia (2017) mengenai "Pengaruh Beban Kerja, Stress Kerja Dan Motivasi Terhadap Kinerja Perawat Di Rumah Sakit Islam Ibnu Sina Pekanbaru" dengan signifikansi nilai $p$ beban kerja $=0,000<0,05$ dan signifikansi nilai $p$ stress kerja $=0,033<$ 0,05 .

4. Pengaruh Kelelahan KerjaTerhadap Kinerja

Hipotesis 4 menyatakan bahwa terdapat pengaruh langsung burnout (Y1) terhadap kinerja perawat (Y2) dengan nilai koefisien sebesar 0,725 dengan signifikansi $0,000<0,05$, sehingga dapat disimpulkan variabelkelelahan kerja(Y1) berpengaruh positif dan signifikan terhadap kinerja perawat (Y2) sehingga hipotesis 4 terbukti, yaitu ada pengaruh yang bermakna antara kelelahan kerjaterhadap kinerja perawat di Rumah Sakit Islam Faisal Makassar tahun 2018. Penelitian ini sejalan dengan penelitian yang dilakukan oleh Sri Pahalendang Asi (2013) mengenai "Pengaruh Dukungan Sosial dan Burnout Terhadap Kinerja Perawat Rawat Inap RSUP Sanglah" dengan signifikansi $p=0,013<0,05$ dimana hal ini membuktikan bahwa semakin tinggi kelelahan kerja, maka akan semakin rendah kinerja perawat. Hal ini sesuai dengan pernyataan responden yang mengatakan kurang bisa menguasai emosi dengan baik.

5. Pengaruh Beban Kerja Terhadap Kinerja

Hipotesis 5 menyatakan bahwa terdapat pengaruh langsung beban kerja (X1) terhadap kinerja perawat (Y2) dengan nilai koefisien sebesar 0,697 dengan signifikansi 0,001, dengan demikian beban kerja berpengaruh positif dan signifikan terhadap kinerja perawat sehingga hipotesis 5 terbukti, yaitu ada pengaruh yang bermakna antara beban kerjaterhadap kinerja perawat di Rumah Sakit Islam Faisal Makassar tahun 2018. Hal ini sejalan dengan penelitian yang dilakukan oleh Friska Aprilia (2017) mengenai "Pengaruh Beban Kerja, Stress Kerja Dan Motivasi Terhadap Kinerja Perawat Di Rumah Sakit Islam Ibnu Sina Pekanbaru" dengan nilai signifikansip = $0,001<0,05$ yang berarti bahwa semakin rendah beban kerja perawat maka akan semakin baik juga kinerjanya. Hal ini sesuai dengan pernyataan responden bahwa beban kerja perawat sudah sesuai dengan kemampuan dan perbandingan antara jumlah perawat sudah sesuai dengan jumlah pasien di tiap ruangan.

6. Pengaruh Stress Kerja Terhadap Kinerja

Hipotesis 6 menyatakan bahwa terdapat pengaruh langsung antara stress kerja (X2) terhadap kinerja perawat (Y2) dengan nilai koefisien sebesar 0,282 dengan signifikansi 0,185>0,05 dengan demikian stress kerja berpengaruh negatif dan tidak signifikan terhadap kinerja perawat sehingga hipotesis 6 tidak terbukti, yaituada pengaruh yang bermakna antara stress kerja terhadap kinerja perawat di Rumah Sakit Islam Faisal Makassar. Penelitian ini sejalan dengan penelitian yang dilakukan olehMuhammad Taufan Akbar (2018) mengenai "Analisis Pengaruh Stress Kerja, Beban Kerja dan Karakteristik Individu Terhadap Kinerja Perawat di RSUD Karanganyar" dengan signifikansi nilai $p=0,064$, yang berarti faktor stress kerja berpengaruh negatif dan tidak signifikan terhadap kinerja perawat, artinya setiap kenaikan stress kerja akan menurunkan kinerja perawat.

7. Pengaruh Beban Kerja Terhadap Kinerja Perawat Melalui Kelelahan Kerja

Hipotesis 7 menyatakan bahwa terdapat pengaruh langsung beban kerja 
(X1) terhadap kinerja perawat (Y2) melalui kelelahan kerja(Y1) dengan nilai koefisien beban kerja sebesar 0,697 , dengan signifikansi sebesar 0,001 sedangkan koefisien kelelahan kerja sebesar 0,725 dan signifikansi 0,000 dengan demikian pengaruh langsung kelelahan kerja lebih besar daripada beban kerja. Hal ini menunjukkan bahwa kelelahan kerja mampu memberikan pengaruh cukup besar sebagai variabel intervening sehingga hipotesis 7 terbukti, yaitu ada pengaruh yang bermakna antara beban kerja terhadap kinerja perawat melalui kelelahan kerja di Rumah Sakit Islam Faisal Makassar. Penelitian ini sejalan dengan penelitian yang dilakukan olehIndah Yulia Kusumaningrum (2016) mengenai "Pengaruh Beban Kerja Dan Karakteristik Individu Terhadap Kinerja Perawat Melalui Burnout Sebagai Variabel Intervening Pada PT. Nusantara Medika Utama RS Perkebunan (Jember Klinik)" dengan koefisien beban kerja terhadap kinerja melalui kelelahan kerja sebesar 0,287 sedangkan pengaruh langsung sebesar 0,294, untuk itu pengaruh langsung lebih besar daripada pengaruh tidak langsung.

8. Pengaruh Beban Kerja, Stress Kerja Dan Kelelahan Kerja Secara Gabungan Terhadap Kinerja Perawat

Hipotesis 8 menyatakan bahwa terdapat pengaruh gabungan antara beban kerja(X1) dan stress kerja (X2) terhadap kinerja perawat secara gabungan melalui kelelahan kerja (Y1) dengan nilai koefisien sebesar 0,697 , $0,282,0,725$ dengan signifikansi sebesar $0,001,0,185,0,000<0,05$ dengan demikian diantara variabel beban kerja, stress kerja dan kelelahan kerja yang paling berpengaruh terhadap kinerja perawat adalah variabel kelelahan kerja kemudian beban kerja dan setelah itu stress kerja sehingga hipotesis 8 diterima yaitu ada pengaruh beban kerja, stress kerja dankelelahan kerja secara gabungan di Rumah Sakit Islam Faisal Makassar. Penelitian ini sejalan dengan penelitian yang dilakukan oleh Muhammad Taufan Akbar (2018) mengenai "Analisis Pengaruh Stress Kerja, Beban Kerja dan Karakteristik Individu Terhadap Kinerja Perawat di RSUD Karanganyar" dengan signifikansi nilai $p=0,064$, yang berarti faktor stress kerja berpengaruh negatif signifikan terhadap kinerja perawat, artinya setiap kenaikan stress kerja akan menurunkan kinerja perawat.

\section{KESIMPULAN}

1. Ada pengaruh yang signifikan antara beban kerja terhadap kelelahan kerja, yang mana jika beban kerja tinggi maka kelelahan kerjapada perawat juga akan meningkat dan Ada pengaruh yang signifikan antara stress kerja terhadap kelelahan kerja, yang mana jika stress kerja tinggi maka kelelahan kerja pada perawat juga meningkat.

2. Ada pengaruh yang signifikan antara beban kerja, stress kerja terhadap kinerja perawat secara gabungan, yang mana jika beban kerja dan stress kerja tinggi maka kinerja perawat juga akan menurun dan Ada pengaruh yang signifikan antara kelelahan kerja terhadap kinerja perawat, yang mana jika kelelahan kerja tinggi maka kinerja perawat akan menurun.

3. Ada pengaruh yang signifikan antara beban kerja terhadap kinerja perawat, yang mana jika beban kerja tinggi maka kinerja perawat akan menurun. Ada pengaruh tetapi tidak signifikan antara stress kerja terhadap kinerja perawat, yang mana jika stress kerja rendah tidak akan berpengaruh terhadap kinerja perawat dan Ada pengaruh yang signifikan antara beban kerja terhadap kinerja perawat melalui kelelahan kerja, yang mana jika kelelahan kerjalebih tinggi maka beban kerja juga akan tinggi sehingga kinerja perawat akan menurun.

4. Ada pengaruh yang signifikan antara beban kerja, stress kerja dan kelelahan kerja secara gabungan terhadap kinerja perawat, yang mana variabel kelelahan kerja adalah variabel yang paling berpengaruh kemudian beban kerja. Kelelahan kerja dan beban kerja berpengaruh positif dan gabungan terhadap kinerja perawat sedangkan stress kerja berpengaruh negatif dan tidak signifikan terhadap kinerja perawat.

5. Ada pengaruh tidak langsung beban kerja terhadap kinerja perawat melalui kelelahan kerja, yang mana jika beban kerja tinggi maka kinerja perawat akan menurun melalui kelelahan kerja. Ada pengaruh tidak langsung stress kerja terhadap kinerja perawat melalui kelelahan kerja, yang mana jika stress kerja tinggi maka kinerja perawat akan menurun melalui kelelahan kerja. 


\section{SARAN}

1. Saran bagi pihak Rumah Sakit Islam Faisal Makassar Untuk meningkatkan kinerja perawat di Rumah Sakit Islam Faisal Makassar, maka pihak manajemen Rumah Sakit perlu memperhatikan dan mengatur kembali faktor - faktor seperti beban kerja, stress kerja dan kelelahan kerja dengan baik serta faktor lingkungan dan sarana prasarana Rumah Sakit yang membuat para perawat merasa nyaman saat bekerja yang akan menghasilkan kinerja dan pelayanan keperawatan yang baik bagi pasien sehingga mampu meningkatkan citra dan mutu pelayanan Rumah Sakit Islam Faisal dimata masyarakat kota Makassar.

2. Saran bagi peneliti selanjutnya Karena variabel yang diteliti dalam penelitian ini hanya variabel beban kerja, stress kerja, kelelahan kerja dan kinerja perawat, maka bagi peneliti selanjutnya yang ingin melakukan penelitian selanjutnya dan meneliti tentang topik yang sama, disarankan untuk mengambil jumlah responden yang lebih banyak dengan variabel yang lebih luas seperti misalnya insentif, gaya kepemimpinan, kepuasan kerja, motivas kerja atau lingkungan kerja dan variabel lain yang mempengaruhi kinerja perawat, mengingat Sumber Daya Manusia itu luas sekali maka sebaiknya perlu mengembangkan ide - ide mengenai penelitian yang akan diambil dengan menggunakan analisis yang baik agar hasil yang didapatkan dari penelitian lebih akurat dan lebih baik.

\section{DAFTAR PUSTAKA}

Alimul.Aziz (2004), Pengantar konsep dasar keperawatan, EGC, Jakarta

Asmadi (2005), Konsep Dasar Keperawatan, EGC, Jakarta

Baharuddin. (2017). Metodologi Penelitian Kuantitatif. Arus Timur. Makassar

Chernis, C. (1980). Staff Burnout. Job Stress in the human service. Beverly Hills, CA: Sage Publications.

Dessler, Gary. (2009). Manajemen Sumber Daya Manusia. Jakarta: Pt Macanan Jaya.

Hawes, K (2009). Nurse job stress, burnout, practice environment and maternal satisfaction in the neonatal intensive care unit. Doctor Dissertatio, Universityof Rhode Island, Provindence, USA.

Mahyar Suara.dkk (2010), Konsep Dasar Keperawatan, TIM. Jakarta.

Maslach, C Jackson, S. E,. \& Leiter, M. (1996). Maslach Burnout Inventory: Manual. Third Edition. Palo Alto, CA: Consulting Psychologists Press.

Moekijat. 2004. Manajemen Tenaga Kerja dan Hubungan Kerja. Bandung. Pioner Jaya.

Mukhlis, S.(2005). Kinerja dan Penilaian Kerja SDM. Jakarta. Intan Pariwara

Notoatmodjo, S. (2010). Metodologi Penelitian Kesehatan. Jakarta: Rineka Cipta.

Perry \& Potter. Buku Ajar Fundamental Keperawatan: Konsep, proses dan praktik. Alih bahasa, Yasmin Asih (et al). Jakarta. EGC.

Schaufeli. W \& Enzmann D. (1998). The Burnout Companion to Study \& Practice: A Crytical Analysis. United Kingdom: T.J International Ltd.

Simanjuntak, P. J. (2005). Manajemen dan Evaluasi Kerja. Jakarta.: Lembaga Penerbit FEUI.

Sedarmayanti. 2011. Manajemen Sumber Daya Manusia, Reformasi, Birokrasi dan Manajemen Pegawai Pegawai Negeri Sipil (cetakan kelima). Bandung. PT. Refika.

Soleman, Aminah. 2011. Analisis Beban Kerja Ditinjau Dari Faktor Usia Dengan Pendekatan Recommended Weiht Limit. Jurnal Arika, Vol.05 No.02

Tawale, E, N., dkk. (2011). Hubungan Antara Motivasi Kerja Perawat Dengan Kecenderungan Mengalami Burnout pada Perawat di RSUD Serui-Papua. Journal Insani, 13,2.

Wirawan. (2009). Evaluasi Kinerja Sumber Daya Manusia: Teori, Aplikasi dan Penelitian. Salemba Empat. Jakart 